Article

\title{
Environmental Sustainability Assessment of Spatial Entities with Anthropogenic Activities-Evaluation of Existing Methods
}

\author{
Despoina Aktsoglou * and Georgios Gaidajis \\ Laboratory of Environmental Management and Industrial Ecology, Department of Production Engineering and \\ Management, Democritus University of Thrace, 67100 Xanthi, Greece; geogai@pme.duth.gr \\ * Correspondence: daktsog@pme.duth.gr; Tel.: +30-25410-79356
}

Received: 19 February 2020; Accepted: 27 March 2020; Published: 29 March 2020

check for updates

\begin{abstract}
The aim of this study is to evaluate the existing available methods that can potentially be applied to anthropogenic spatial entities to access their environmental sustainability. The paper offers an overview of existing sustainability assessment methods, discusses their adequacy, and evaluates their efficiency to assess the environmental sustainability of anthropogenic spatial entities. From a list of sixty-one (61) sustainability assessment methods for spatial entities with anthropogenic activities that had been identified and examined, thirteen (13) methods were selected to be assessed based on specific exclusion criteria set. The thirteen methods were further classified into four categories, namely, (1) Indicators/Indices, (2) Resource Availability Assessment, (3) Material and Energy Flow Analysis, and (4) Life-Cycle Assessment, and then these methods were evaluated using specific evaluation criteria. The "Resource Availability Assessment" category, and particularly the "Ecological Footprint" method, was indicated as the most appropriate method to assess the environmental sustainability of anthropogenic spatial entities.
\end{abstract}

Keywords: environmental sustainability; sustainable development; environmental assessment; anthropogenic spatial entities

\section{Introduction}

The growth of the human population enhances the extensive use and consumption of materials, while the existing lifestyle and established consumer patterns lead the planet and its population to an unstable situation without possible reversal [1]. In other words, the rate of use and consumption of resources and material, especially in developed countries, cannot be maintained without causing significant damage to the environment, society, and economy. Therefore, keeping anthropogenic systems sustainable is of crucial importance; but how do we define, maintain, and finally measure sustainability?

According to Graymore et al. [2], "sustainability is an essential goal for planning and natural resource management at all spatial scales", as it requires the population to live within the limits of the supporting systems, ensuring equitable sharing of resources and opportunities for this and future generations [3].

Moreover, the measurement and the assessment of sustainability is a particularly complex process due to the wide range of issues and the complexity of the systems involved. As mentioned by Gasparatos et al. [4], "the sustainability assessment does the difficult job to discover, study and suggest solutions for a large and heterogeneous set of issues that concern the stakeholders and extend to different spatial and temporal scales".

According to Ness et al. [5], "The purpose of sustainability assessment is to provide decision-makers with an evaluation of global to local integrated nature-society systems in short and long term 
perspectives in order to assist them to determine which actions should or should not be taken in an attempt to make society sustainable". It is clear from the above definition that sustainability assessment mainly evolves as a decision-making tool [6].

During the last decades, strategic planning and natural resource management are increasingly attempted at anthropogenic spatial entity scale, which refers to the spatial scale below a nation and usually includes a province or a municipality or parts of them that are under a specific management scheme or other specific authority (ex. National park). This spatial scale is the most appropriate for this purpose as it is "at this scale where ecological functioning and human activities most intensely interact" [7] and "the governance for planning, coordinating and assessing actions towards sustainable development" is effective at the specific scale [8].

There are hundreds of sustainability assessment methods [9]. Several studies [4,5,9-14] have attempted to summarize relevant methods. However, "we are still far from agreeing on how to define, plan and measure the progress towards sustainability" [10].

Most of the terms of sustainability are associated principally with the environment [15], since environmental protection is essential for sustainable development [16]. Therefore, the environmental aspects of sustainability are at the forefront [14], and the concept of environmental sustainability assessment integrates the environmental component in the decision-making process, providing deeper and more formalized knowledge [13]. Angelakoglou and Gaidajis [14] define an environmental sustainability assessment method as "a method which can provide quantitative information that can potentially help to assess the environmental sustainability".

Considering the above, a literature review of available sustainability assessment methods at anthropogenic spatial entity scale was implemented by the authors of this article, in order to assess the methods' adequacy. The literature reviews include (1) the methodology of the review and a brief description of the selected methods, (2) the criteria of the assessment and the reasoning behind their selection, and finally (3) the results of the methods' assessment.

\section{Methodology of Literature Search}

The literature search was implemented utilizing appropriate keywords relevant to the notions of sustainability, sustainability assessment, regional/local environmental sustainability assessment, etc., to specific search engines. As a result, articles with similar themes that had been published in international scientific journals were selected.

The methods emerged from the initial "filtering process" were thoroughly analyzed. Due to the wide range of the particular research area, a set of exclusion criteria was set and several methods were eliminated based on these criteria. In Table 1, the exclusion criteria and the excluded methods are summarized.

Table 1. Exclusion criteria of initially selected methods.

\begin{tabular}{|c|c|c|c|}
\hline & Exclusion Criterion & $\begin{array}{l}\text { Methods Excluded and a Brief Description of their } \\
\text { Exclusion }\end{array}$ & References \\
\hline 1 & $\begin{array}{l}\text { Proven quality of } \\
\text { references }\end{array}$ & $\begin{array}{l}\text { (1) The method "Two Synthetic Environmental Indices" } \\
\text { was excluded due to insufficient data for its analysis. }\end{array}$ & [11] \\
\hline 2 & $\begin{array}{c}\text { Ability to simultaneously } \\
\text { evaluate various } \\
\text { anthropogenic activities }\end{array}$ & $\begin{array}{l}\text { (2) The method "Sustainability/Environmental Rating } \\
\text { Systems" was excluded because it is focused on the } \\
\text { evaluation of Construction Industry. } \\
\text { (3) The method "Environmental Performance Index" } \\
\text { was excluded because it is focused on the evaluation of } \\
\text { human health. }\end{array}$ & [11] \\
\hline
\end{tabular}


Table 1. Cont.

\begin{tabular}{|c|c|c|c|}
\hline & Exclusion Criterion & $\begin{array}{l}\text { Methods Excluded and a Brief Description of their } \\
\text { Exclusion }\end{array}$ & References \\
\hline 3 & $\begin{array}{l}\text { Holistic evaluation at } \\
\text { local level (region, } \\
\text { municipality) }\end{array}$ & $\begin{array}{c}\text { Methods } 4 \text { to } 19 \text { were excluded because they are } \\
\text { developed to assess specific projects: } \\
\text { (4) Environmental Quality Index; } \\
\text { (5) Cost-Benefit Analysis; } \\
\text { (6) Multicriteria Analysis; } \\
\text { (7) Full Cost Accounting; } \\
\text { (8) Sustainability Assessment Modeling; } \\
\text { Analysis; } \\
\text { (9) Environmental, Social, and Economic Impact } \\
\text { (10) Analysis Network Process; } \\
\text { (11) Environmental Impact Assessment; } \\
\text { (12)EU Sustainability Impact Assessment; } \\
\text { (13)Strategic Environmental Assessment; } \\
\text { (14) Material Intensity per Service Unit; } \\
\text { (15) Risk Analysis; } \\
\text { (16) Conceptual Modeling; } \\
\text { (17) System Dynamics; } \\
\text { (18) Uncertainty Analysis; } \\
\text { (19) Vulnerability analysis. } \\
\text { implemented on a national scale: } \\
\text { (20) UNCSD 58; } \\
\text { (21) Sustainable National Income; } \\
\text { Methods 20 to were excluded because they are only } \\
\text { (23) Wellbeing Index; } \\
\text { Economic Welfare; } \\
\text { (24) Genuine Progress Indicator and Index of Sustainable } \\
\text { (25) Human Development Index; } \\
\text { (26) Environmental Sustainability Index; } \\
\text { (27) Environment Sustainability Index; } \\
\text { (28) Environmental Policy Performance Indicator; } \\
\text { (29) Ecosystem Health Assessment. }\end{array}$ & $\begin{array}{c}{[11]} \\
{[5,9,10,17]} \\
{[5,9,10,17]} \\
{[10]} \\
{[10]} \\
{[9]} \\
{[9]} \\
{[5,17]} \\
{[17]} \\
{[9,17]} \\
{[5]} \\
{[5]} \\
{[5]} \\
{[5]} \\
{[5]} \\
{[5]} \\
\\
{[5]} \\
{[5]} \\
{[5]} \\
{[5]} \\
{[5,17]} \\
{[5,17]} \\
{[11]} \\
{[11]} \\
{[11]} \\
{[2]}\end{array}$ \\
\hline 4 & $\begin{array}{c}\text { Focus on the sustainable } \\
\text { aspect of environmental } \\
\text { performance }\end{array}$ & $\begin{array}{l}\text { Methods } 30 \text { to } 39 \text { were excluded because they mainly } \\
\text { assess public concern about the environmental impact of } \\
\text { projects or activities: } \\
\text { (30) Concern about Environmental Problems; } \\
\text { (31) Index of Environmental Friendliness; } \\
\text { (32) Environmental Vulnerability Index; } \\
\text { (33) Market prices; } \\
\text { (34) Benefit transfer; } \\
\text { (35) Choice modeling; } \\
\text { (36) Hedonic pricing; } \\
\text { (37) Travel Cost Method; } \\
\text { (38) Contingent Valuation Method; } \\
\text { (39) Community Impact Evaluation. }\end{array}$ & $\begin{array}{c}{[11]} \\
{[11]} \\
{[11]} \\
{[10]} \\
{[10]} \\
{[10]} \\
{[9,10]} \\
{[9,10]} \\
{[9,10]} \\
{[9]}\end{array}$ \\
\hline 5 & $\begin{array}{l}\text { Basic idea analysis } \\
\text { (when it comes to a } \\
\text { family of methods } \\
\text { resulting from the } \\
\text { extension, improvement, } \\
\text { or segmentation of an } \\
\text { original method) }\end{array}$ & $\begin{array}{l}\text { Methods } 40 \text { to } 47 \text { were excluded because they belong to } \\
\text { the same family of methods with the method "Ecological } \\
\text { Footprint": } \\
\text { (40) Carrying Capacity; } \\
\text { (41) Natural Resource Availability; } \\
\text { (42) Carbon Footprint; } \\
\text { (43) Fossil Fuel Sustainability Index; } \\
\text { (44) Green Gas Inventory; } \\
\text { (45) Eco-Index Methodology; } \\
\text { (46) Sustainable Process Index; } \\
\text { (47) Energy Footprint. } \\
\text { (48) The method "Ecological Network Analysis" was } \\
\text { excluded because it is developed in the same basic idea } \\
\text { with the method "Physical Input-Output Tables". }\end{array}$ & $\begin{array}{l}{[18]} \\
{[19]} \\
{[12]} \\
{[11]} \\
{[20]} \\
{[21]} \\
{[22]} \\
{[23]} \\
\\
{[13]}\end{array}$ \\
\hline
\end{tabular}


To sum up the above, from a list of sixty-one (61) examined methods that assess environmental sustainability of a spatial entity with anthropogenic activities, forty-eight (48) were excluded and thirteen (13) methods were finally selected (Table 3). Although not exhaustive, this list is, in the authors' opinion, extremely satisfactory.

In order to facilitate their analysis, the thirteen selected methods were classified based on their particular characteristics and their basic idea in four (4) categories, namely, "Indicators/Indices", "Resource Availability Assessment", "Material and Energy Flow Analysis", and "Life-Cycle Assessment" (see Table 3). The specific categorization is based on the categorization proposed by Angelakoglou and Gaidajis [14] and is widely acceptable in the economic sectors [24].

Table 2. The categorization of the selected methods and their brief description.

\begin{tabular}{|c|c|c|}
\hline & Method & Description of Method \\
\hline \multicolumn{3}{|r|}{ Indicators/Indices } \\
\hline 1.1 & $\begin{array}{l}\text { Sustainable Development } \\
\text { Indicators (SDIs) }\end{array}$ & $\begin{array}{l}\text { The SDIs consist a specific range of indicators for sustainable } \\
\text { development, which have been developed according to the Driving } \\
\text { Force-pressure-state-impact-response (DPSIR) framework, in order } \\
\text { to support the stakeholders to evaluate the effectiveness of the } \\
\text { policy on the way to sustainable development }[8,25] \text {. }\end{array}$ \\
\hline 1.2 & $\begin{array}{l}\text { Environmental Pressure Indicators } \\
\text { (EPIs) }\end{array}$ & $\begin{array}{l}\text { The EPIs have been developed by Eurostat and consist of sixty (60) } \\
\text { indicators, six (6) for each of the ten (10) policy areas according to } \\
\text { the 5th Environmental Action Program [26]. }\end{array}$ \\
\hline 1.3 & $\begin{array}{l}\text { The Dashboard of Sustainability } \\
\text { (DoS) }\end{array}$ & $\begin{array}{l}\text { The DoS method is a mathematical and graphical tool, designed to } \\
\text { integrate the complex implications of sustainability and to support } \\
\text { the decision-making process at nation level with the generation of } \\
\text { brief evaluations. The tool evaluates indicators relative to } \\
\text { environmental protection, economic development and social } \\
\text { improvement [27]. }\end{array}$ \\
\hline \multirow[t]{2}{*}{1.4} & Quality of Life (QoL) & $\begin{array}{l}\text { The method is based on trends and conditions related to indicators } \\
\text { such as crime, participation in cultural activities, health, education, } \\
\text { income, unemployment, water quality, air pollution and the } \\
\text { proportion of unstructured areas, assessing the relevant areas of } \\
\text { "Quality of Life" [28]. }\end{array}$ \\
\hline & \multicolumn{2}{|r|}{ Resource Availability Assessment } \\
\hline 2.1 & Ecological Footprint (EF) & $\begin{array}{l}\text { The Ecological Footprint [29] expresses «the theoretical area (in } \\
\text { global hectares) which is used by humans to produce the resources } \\
\text { they consume, and to absorb the waste generated (including CO2 } \\
\text { emissions from energy consumption)". }\end{array}$ \\
\hline 2.2 & Water Footprint (WF) & $\begin{array}{l}\text { The WF method [30] is based on the calculation of the "total volume } \\
\text { of fresh water required to meet the direct and/or indirect needs of } \\
\text { the entity under consideration". }\end{array}$ \\
\hline \multirow[t]{2}{*}{2.3} & Wellbeing Assessment (WA) & $\begin{array}{c}\text { The method has been developed by the World Conservation Union } \\
\text { for its use at various levels of spatial entities. This is a holistic } \\
\text { approach to evaluating sustainability using plenty of indicators, } \\
\text { covering all parts of the entity [31]. }\end{array}$ \\
\hline & \multicolumn{2}{|r|}{ Material and Energy Flow Analysis } \\
\hline 3.1 & Material Flow Analysis (MFA) & $\begin{array}{l}\text { The MFA method is used to determine the material and energy } \\
\text { balance of an entity. This method is mostly implemented at national } \\
\text { level due to the easy access to the required data and the existence of } \\
\text { a methodological framework developed by Eurostat [32]. }\end{array}$ \\
\hline 3.2 & Substance Flow Analysis (SFA) & $\begin{array}{c}\text { The SFA method }[33,34] \text { aims at the control of the flows of } \\
\text { substances (chemicals and/or compounds) that contain significant } \\
\text { levels of concern about their impact on ecological and human health } \\
\text { in their production and use. }\end{array}$ \\
\hline 3.3 & $\begin{array}{c}\text { Physical Input-Output Tables } \\
\text { (PIOT) }\end{array}$ & $\begin{array}{l}\text { The methods study the direct and indirect flows of an entity, } \\
\text { applying the principle of mass conservation. Especially, the PIOT } \\
\text { considers the environment as a source of raw materials and a "sink" } \\
\text { of the residuals of the production processes of an economy [35]. }\end{array}$ \\
\hline
\end{tabular}


Table 3. The categorization of the selected methods and their brief description.

\begin{tabular}{|c|c|c|}
\hline & Method & Description of Method \\
\hline & & Material and Energy Flow Analysis \\
\hline 3.4 & Emergy Analysis (EMA) & $\begin{array}{l}\text { The EMA [36] method is used to measure "the work previously } \\
\text { done by nature and/or man that contributed to the realization of a } \\
\text { product or service". The energy required is expressed as the sum of } \\
\text { the individual types of energy, expressed as a final form of energy, } \\
\text { usually solar energy (expressed in emjoules). }\end{array}$ \\
\hline \multirow[t]{2}{*}{3.5} & Exergy Analysis (EXA) & $\begin{array}{l}\text { The EXA method [37] is used to measure "the maximum equivalent } \\
\text { mechanical work that can be derived from a system when it tends to } \\
\text { a thermodynamic equilibrium state compared with a reference } \\
\text { system. The application of the method allows the definition and } \\
\text { evaluation of the flows that contain exergy (so it is possible to be } \\
\text { further exploited) or where it is completely lost (so it has to be } \\
\text { further analyzed) [38]. }\end{array}$ \\
\hline & \multicolumn{2}{|r|}{ Life-Cycle Assessment } \\
\hline 4.1 & $\begin{array}{l}\text { Life-Cycle Sustainability Analysis } \\
\text { (LCSA) }\end{array}$ & $\begin{array}{l}\text { The Life-Cycle Assessment (LCA) is mostly applied to assess and } \\
\text { evaluate product sustainability. However, Guinée et al. [39] } \\
\text { proposed a new framework, namely Life-Cycle Sustainability } \\
\text { Analysis, which extends the scope of analysis from product-related } \\
\text { to economic issues, including an intermediate level, like } \\
\text { anthropogenic spatial entities. }\end{array}$ \\
\hline
\end{tabular}

\section{Assessment of Selected Methods}

The scope of the evaluation of the selected 13 methods is the selection of the most appropriate method for assessing the environmental sustainability of anthropogenic spatial entities. Furthermore, the evaluation aims to document whether there is a necessity to develop new methods (or/and improving the available ones). Within that framework, the thirteen (13) methods, mentioned above, were assessed using predefined evaluation criteria.

Each method has specific advantages and disadvantages associated with its particular characteristics. However, the general features that an efficient method of evaluating sustainability must, as described (a) in the literature $[4,24,40],(b)$ in the definition of sustainability, and (c) as defined by the requirements of the end-user, i.e., addressing issues related to its applicability and usability [2], do the following [14]:

- Take into account the particular spatial characteristics of the anthropogenic spatial entity under consideration and be able to evaluate its progress over time.

- Enhance decision-making on promoting desired actions that improve sustainability and the possibility of adding new activities within the administrative boundaries of the spatial entity.

- Establish sustainability reference benchmarks.

- Ensure an adequate balance between the level of complexity and the coverage of key sustainability issues.

- Emphasize clearly and minimize assumptions and weaknesses that arise during its development.

- Be appropriate for comparisons.

- Ensure that it can be modified to incorporate other aspects of sustainability or that it can be combined with other methods to implement a more comprehensive assessment.

Therefore, based on the above characteristics that a sustainability assessment method should have, five criteria listed in Table 4 were selected to evaluate the 13 methods selected. More specifically, the methods were evaluated with the application of a zero to three scale, where zero indicates the minimum and three the maximum satisfaction of the criterion. For each criterion, three questions were developed based on the characteristics previously mentioned. If the examined method satisfies the issue raised by the question (answer to the question "Yes"), then it receives one point. Alternatively, no point is attributed to the method (answer to the question ' $\mathrm{No}^{\prime}$ ). Therefore, the maximum score 
for each method can be 15 points (five criteria and three questions for each criterion). Higher score implies higher satisfaction of all evaluation criteria, and consequently higher suitability for assessing environmental sustainability.

At this point, it should be mentioned that the authors recognize a certain degree of subjectivity in the evaluation process, as the satisfaction of the criteria for each of the 13 methods was judged not by a focus group but according to the analysis of the methods made by the authors and the corresponding literature [2], which referred to similar criteria for evaluating a subset of the specific methods. Among the future objectives of the authors is the more objective evaluation of the aforementioned methods with the assistance of an experts group.

\section{Results and Discussion}

The evaluation of the methods is presented in detail in Table 4.

The methods belonging to the Second Category, i.e., "Resource Availability Assessment Methods", exhibit the highest average score in terms of satisfaction of all the evaluation criteria (11 points out of the maximum 15 points). More specifically, the Method 2.1 "Ecological Footprint (EF)" of the Second Category of Methods exhibits the highest degree of satisfaction for all criteria (13 points out of the maximum 15 points), followed by the Method 2.3 "Wellbeing Assessment (WA)" of the same Category (11/15), the Method 1.1 "Sustainable Development Indicator Method", and the Method 1.4 "Quality of Life" of the First Category of Methods. The EF method was the highest rated method with a total score of 13/15. Particularly, the Ecological Footprint has the ability to assess environmental sustainability holistically (Criterion 1 score: $3 / 3$ ), is easy to use (Criterion 4 score: 3/3), and integrates spatial and temporal characteristics of the anthropogenic spatial entity under study (Criterion 5 score: 3/3). All Methods of Category 2 satisfy to a maximum degree Criterion 5 ("Integration of spatial/temporal characteristics") and extremely well Criterion 1 ("Ability to access environmental sustainability holistically"), satisfying therefore the spatial and temporal expansion of assessment and the holistic approach of the assessment.

The assessment of all categories and methods identified some issues that need improvement, such as the ability of methods to incorporate new activities within the environmental boundaries of the anthropogenic spatial entity under study (Q.2.2: Score 0). Moreover, few methods include specific thresholds in order to evaluate quantitatively whether the performance is sustainable (Q.3.2.: Score 4).

An ideal method of evaluating sustainability should take into account all the parameters simultaneously [5]. However, the development of such a method, due to the nature of the concept of sustainability, involves a high degree of complexity, which in the case of anthropogenic spatial entities translates into high costs and time.

A new methodological framework in assessing environmental sustainability for spatial entities with anthropogenic activities that will be able to take advantages of the existing methods and deal with their challenges and their drawbacks should be developed. The scope of the framework will be to constitute a tool of particular importance for the decision-making process at the local level [14,17], giving answers to the issues highlighted above. 
Table 4. Evaluation of the environmental sustainability assessment methods under examination.

\begin{tabular}{|c|c|c|c|c|c|c|c|c|c|c|c|c|c|c|c|}
\hline \multirow{3}{*}{ Evaluation Criteria } & \multicolumn{13}{|c|}{ Categorization of Methods } & \multirow{3}{*}{$\begin{array}{l}\text { Criterion } \\
\text { Average }\end{array}$} & \multirow{3}{*}{$\begin{array}{c}\text { Question } \\
\text { Score }\end{array}$} \\
\hline & \multicolumn{4}{|c|}{1 Indicators/Indices } & \multicolumn{3}{|c|}{$\begin{array}{l}2 \text { Resource Availability } \\
\text { Assessment }\end{array}$} & \multicolumn{5}{|c|}{3 Material and Energy Flow Analysis } & \multirow{2}{*}{$\begin{array}{c}\text { 4 Life-Cycle } \\
\text { Assessment } \\
4.1 \\
\text { LCSA }\end{array}$} & & \\
\hline & $1.1 \mathrm{SDI}$ & 1.2 EPI & $\begin{array}{c}1.3 \\
\text { DoS }\end{array}$ & $1.4 \mathrm{QoL}$ & $2.1 \mathrm{EF}$ & $2.2 \mathrm{WF}$ & $\begin{array}{r}2.3 \\
\text { WA }\end{array}$ & $\begin{array}{c}3.1 \\
\text { MFA }\end{array}$ & $3.2 \mathrm{SFA}$ & $\begin{array}{c}3.3 \\
\text { PIOT }\end{array}$ & $\begin{array}{c}3.4 \\
\text { EmA }\end{array}$ & $\begin{array}{r}3.5 \\
\text { ExA }\end{array}$ & & & \\
\hline \multicolumn{14}{|c|}{ Criterion 1: Ability to assess environmental sustainability holistically } & \multicolumn{2}{|c|}{2.3} \\
\hline $\begin{array}{l}\text { Q.1.1: Do methods assess more } \\
\text { than one sector? }\end{array}$ & Y & Y & Y & Y & Y & Y & $\mathrm{Y}$ & $\mathrm{Y}$ & $\mathrm{Y}$ & Y & $\mathrm{Y}$ & Y & Y & & 13 \\
\hline $\begin{array}{l}\text { Q.1.2: Do methods assess an } \\
\text { adequate number of } \\
\text { environmental issues? }\end{array}$ & $\mathrm{Y}$ & Y & $\mathrm{N}$ & Y & $\mathrm{Y}$ & $\mathrm{N}$ & $\mathrm{Y}$ & $\mathrm{Y}$ & $\mathrm{N}$ & $\mathrm{N}$ & $\mathrm{N}$ & $\mathrm{N}$ & $\mathrm{Y}$ & & 7 \\
\hline $\begin{array}{l}\text { Q.1.3: Do methods promote } \\
\text { energy and resource efficiency? }\end{array}$ & Y & $\mathrm{N}$ & $\mathrm{N}$ & $\mathrm{N}$ & Y & $\mathrm{Y}$ & $\mathrm{Y}$ & $\mathrm{Y}$ & Y & $\mathrm{Y}$ & $\mathrm{Y}$ & Y & Y & & 10 \\
\hline $\begin{array}{l}\text { Score per criterion } \\
\text { Average Score of each category }\end{array}$ & 3 & 2 & 1 & 2 & 3 & $\begin{array}{c}2 \\
2.7\end{array}$ & 3 & 3 & 2 & $\begin{array}{c}2 \\
2.2\end{array}$ & 2 & 2 & $\begin{array}{l}3 \\
3\end{array}$ & & \\
\hline \multicolumn{14}{|c|}{ Criterion 2: Ability to help decision making } & \multicolumn{2}{|c|}{1.3} \\
\hline $\begin{array}{l}\text { Q.2.1: Can methods } \\
\text { communicate their results to } \\
\text { public? }\end{array}$ & $\mathrm{Y}$ & Y & $\mathrm{Y}$ & Y & $\mathrm{Y}$ & $\mathrm{Y}$ & Y & $\mathrm{N}$ & $\mathrm{N}$ & $\mathrm{N}$ & $\mathrm{N}$ & $\mathrm{N}$ & $\mathrm{N}$ & & 7 \\
\hline $\begin{array}{l}\text { Q.2.2: Can methods answer to } \\
\text { the potential addition of a new } \\
\text { activity; }\end{array}$ & $\mathrm{N}$ & $\mathrm{N}$ & $\mathrm{N}$ & $\mathrm{N}$ & $\mathrm{N}$ & $\mathrm{N}$ & $\mathrm{N}$ & $\mathrm{N}$ & $\mathrm{N}$ & $\mathrm{N}$ & $\mathrm{N}$ & $\mathrm{N}$ & $\mathrm{N}$ & & 0 \\
\hline $\begin{array}{l}\text { Score per criterion } \\
\text { Average Score of each category }\end{array}$ & 2 & 2 & 2 & 2 & 2 & $\begin{array}{l}2 \\
2\end{array}$ & 2 & 1 & 1 & $\begin{array}{c}0 \\
0.6\end{array}$ & 0 & 1 & $\begin{array}{l}0 \\
0\end{array}$ & & \\
\hline \multicolumn{14}{|c|}{ Criterion 3: Potential for benchmarking } & \multicolumn{2}{|c|}{1.3} \\
\hline $\begin{array}{l}\text { Q.3.1: Can methods aggregate } \\
\text { the results into single scores? } \\
\text { O.3.2. Do methods include }\end{array}$ & $\mathrm{N}$ & Y & $\mathrm{N}$ & $\mathrm{N}$ & $\mathrm{Y}$ & $\mathrm{Y}$ & $\mathrm{Y}$ & $\mathrm{N}$ & $\mathrm{N}$ & $\mathrm{Y}$ & $\mathrm{Y}$ & $\mathrm{Y}$ & Y & & 8 \\
\hline $\begin{array}{l}\text { specific thresholds/targets of } \\
\text { sustainable performance? }\end{array}$ & $\mathrm{Y}$ & $\mathrm{N}$ & $\mathrm{N}$ & Y & Y & $\mathrm{N}$ & $\mathrm{N}$ & $\mathrm{N}$ & $\mathrm{N}$ & $\mathrm{N}$ & $\mathrm{N}$ & $\mathrm{Y}$ & $\mathrm{N}$ & & 4 \\
\hline $\begin{array}{l}\text { Q.3.3: Can methods be } \\
\text { applied/updated to compare } \\
\text { overall sustainability? }\end{array}$ & $\mathrm{Y}$ & $\mathrm{N}$ & $\mathrm{Y}$ & $\mathrm{Y}$ & $\mathrm{N}$ & $\mathrm{N}$ & $\mathrm{Y}$ & $\mathrm{N}$ & $\mathrm{N}$ & $\mathrm{Y}$ & $\mathrm{N}$ & $\mathrm{N}$ & $\mathrm{N}$ & & 5 \\
\hline Score per criterion & 2 & 1 & 1 & 2 & 2 & 1 & 2 & 0 & 0 & 2 & 1 & 2 & 1 & & \\
\hline Average Score of each category & & & .5 & & & 1.7 & & & & 1 & & & 1 & & \\
\hline
\end{tabular}


Table 4. Cont.

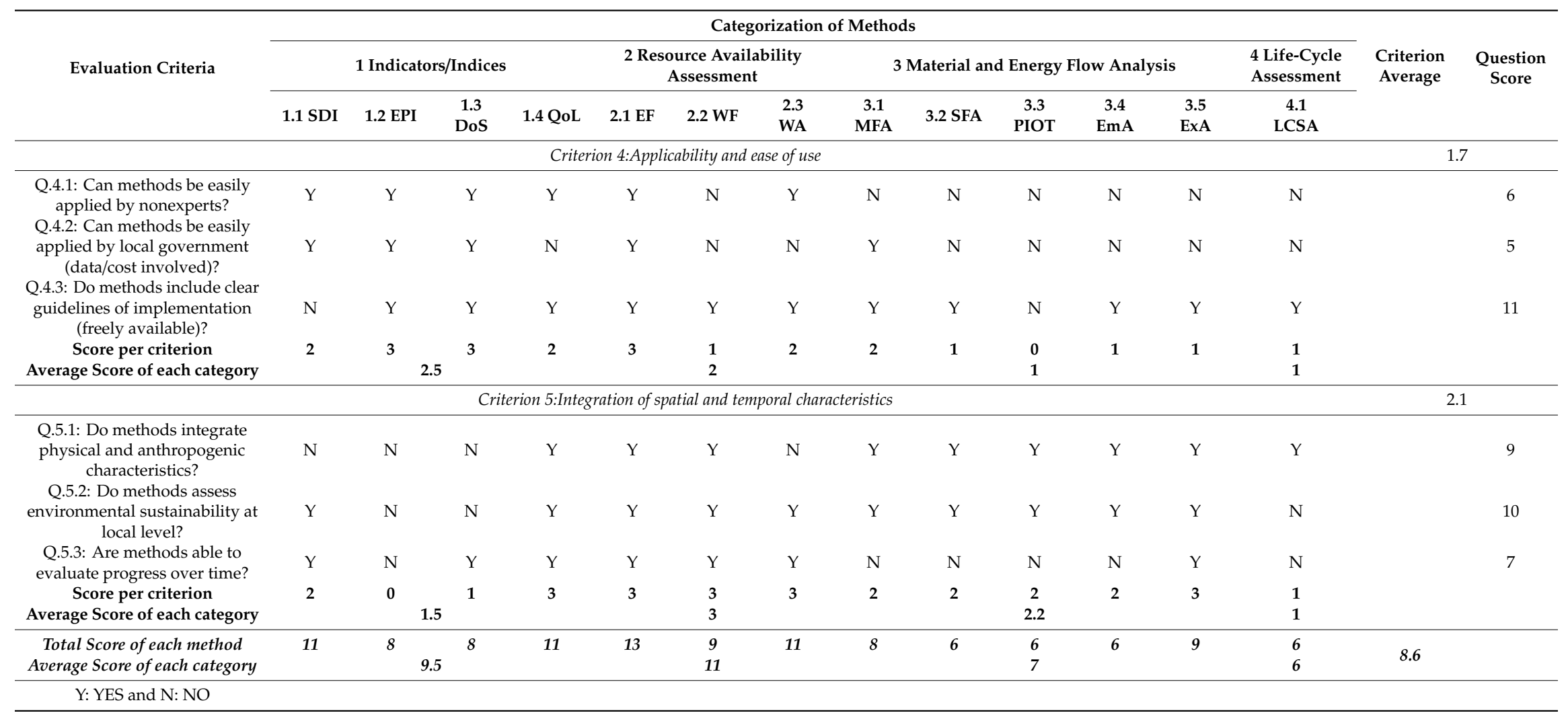




\section{Conclusions}

The scope of this article is to summarize and evaluate the available methods for assessing the environmental sustainability of spatial entities with anthropogenic activities (for example, municipalities, regions, protected areas, and national parks). To achieve this, a literature search of existing methods for assessing the environmental sustainability of anthropogenic spatial entities was carried out. From the total of 61 methods that were found and reviewed, 48 were excluded based on specific exclusion criteria related to the proven quality of the references, the ability to simultaneously evaluate different issues of anthropogenic activity, the holistic evaluation at local level, and the focus on the sustainable aspect of environmental performance.

The 13 finally selected methods were classified according to their particular characteristics into categories, and the methods were evaluated with specific criteria such as the ability to holistically assess environmental sustainability, the ability to support the decision-making process, the ability to perform benchmarking, the applicability and ease of use, and the integration of spatial and temporal characteristics of the entity under study.

The evaluation of available methods, based on the above criteria, indicated that the methods of the "Resource Availability Assessment" category satisfy to a significant extent all the criteria set, whereas a method of the above category, and more specifically the "Ecological Footprint Method" satisfied to a maximum degree the criteria set and was considered therefore as the most appropriate method for assessing the environmental sustainability of a spatial entity with anthropogenic activities.

Further research is necessary in order to indentify methods that are able to assess economic and social sustainability, hence a more holistic inventory of sustainability assessment methods for spatial entities with anthropogenic activities will be developed. The evaluation process followed provides a basis to address the effectiveness of the methods, to develop evaluation criteria, and to select the most suitable method in any case. Future work by the authors will be undertaken to improve the above-mentioned issues.

Results presented in this study can be further utilized to improve current methods and/or develop new ones. The authors are planning to take advantage of these findings and develop an environmental sustainability assessment framework for spatial entities that will be based on the most appropriate method as mentioned, thus the "Ecological Footprint", which will be able to deal with the most shortcomings of the existing methods.

Author Contributions: All authors contributed equally to the text. All authors have read and agreed to the published version of the manuscript.

Funding: This research received no external funding.

Conflicts of Interest: The authors declare no conflict of interest.

\section{References}

1. Allenby, B.R.; Graedel, T.E. Industrial Ecology, 2nd ed.; Pearson Prentice Hall: Upper Saddle River, NJ, USA, 2002; pp. 25-27.

2. Graymore, M.L.M.; Sipe, N.G.; Rickson, R.E. Regional sustainability: How useful are current tools of sustainability assessment at the regional scale? Ecol. Econ. 2008, 67, 362-372. [CrossRef]

3. Graymore, M. The Journey to Sustainability: Small Regions, Sustainable Carrying Capacity and Sustainability Assessment Methods. Ph.D. Thesis, Australian School of Environmental Studies, Griffith University, Brisbane, Australia, 2005.

4. Gasparatos, A.; El-Haram, M.; Horner, M. A critical review of reductionist approaches for assessing the progress towards sustainability. Environ. Impact Assess. Rev. 2008, 289, 286-311. [CrossRef]

5. Ness, B.; Urbel_Piirsalu, E.; Andeberg, S.; Olsson, L. Categorising tools FOS sustainability assessment. Ecol. Econ. 2007, 60, 498-508. [CrossRef]

6. Pope, J.; Annandale, D.; Morrison Sanders, A. Conceptualizing sustainability assessment. Environ. Impact Assess. Rev. 2004, 24, 595-616. [CrossRef] 
7. Coehlo, P.; Mascarenhas, A.; Vaz, P.; Beja, I.; Dores, A.; Ramos, T.B. A Methodological Framework for Indicators of Sustainable Development at the Regional Scale: The Case of the Portuguese Region (Algarve). In Proceedings of the 12th Annual International Sustainable Development Research Conference 2006, Hong Kong, China, 6-8 April 2006; University of Hong Kong, in Association with ERP Environment: Hong Kong, China, 2006.

8. Mascarenhas, A.; Coelho, P.; Subtil, E.; Ramos, T.B. The role of common local indicators in regional sustainability assessment. Ecol. Indic. 2010, 10, 646-656. [CrossRef]

9. Poveda, C.A.; Lipsett, M.G. A review of sustainability assessment and sustainability/environmental rating systems and credit weighting tools. J. Sustain. Dev. 2011, 4, 36-55. [CrossRef]

10. Gasparatos, A.; Scolobig, A. Choosing the most appropriate sustainability assessment tool. Ecol. Econ. 2012, 80, 1-7. [CrossRef]

11. Singh, R.K.; Murty, H.R.; Gupta, S.K.; Dikshit, A.K. An overview of sustainability assessment methodologies. Ecol. Indic. 2012, 15, 281-299. [CrossRef]

12. Cucek, L.; Klemes, J.J.; Kravanja, Z. A review of Footprint analysis tools for monitoring impacts on sustainability. J. Clean. Prod. 2012, 34, 9-20. [CrossRef]

13. Loiseau, E.; Junqua, G.; Roux, P.H.; Bellon-Maurel, V. Environmental assessment of a territory: An overview of existing tools and methods. J. Environ. Manag. 2012, 112, 213-225. [CrossRef]

14. Angelakoglou, K.; Gaidajis, G. A review of methods contributing to the assessment of the environmental sustainability of industrial systems. J. Clean. Prod. 2015, 108, 725-747. [CrossRef]

15. Glavic, P.; Lukman, R. Review of sustainability terms and their definitions. J. Clean. Prod. 2007, 15, 1875-1885. [CrossRef]

16. Collin, R.M.; Collin, R.W. Encyclopedia of Sustainability; ABC-CLIO/Greenwood Press: Santa Barbara, CA, USA, 2010; Volume 2, pp. 101-113.

17. Sala, S.; Ciuffo, B.; Nijkamp, P. A systemic framework for sustainability assessment. Ecol. Econ. 2015, 119, 314-325. [CrossRef]

18. Lane, M.C. The Carrying Capacity Imperative: Assessing Regional Carrying Capacity Methodologies for Sustainable Land-use Planning. In Proceedings of the 53rd Annual Meeting of the International Society for the Systems Sciences, Brisbane, Queensland, Australia, 12-17 July 2009; University of Queensland: Queensland, Australia, 2009.

19. Graymore, M.L.; Sipe, N.G.; Rickson, R.E. Sustaining Human Carrying Capacity: A tool for regional sustainability assessment. Ecol. Econ. 2010, 69, 459-468. [CrossRef]

20. Pulselli, F.; Ciampalini, F.; Leipert, C.; Tiezzi, E. Integrating methods for environmental sustainability: The SPIn-Eco Project in the Province of Siena (Italy). J. Environ. Manag. 2008, 86, 332-341. [CrossRef] [PubMed]

21. Chambers, N.; Simmons, C.; Wackernagel, M. Chapter 9: Assessing Impact of organizations and Services. In Sharing Natures's Interest: Ecological Footprints as an Indicator of Sustainability; Earthscan: London, UK, 2000; p. 145.

22. Kettl, K.H.; Niemetz, N.; Sandor, N.; Eder, M.; Heckl, I.; Narodoslawsky, M. Regional Optimizer (RegiOpt)Sustainable energy technology network solution for regions. Comput. Aided Chem. Eng. 2011, 29, 1959-1963.

23. Global Footprint Network (Glossary 2009). Available online: www.footprintnetwork.org (accessed on 3 February 2017).

24. OECD 2009. Chapter 3: Tracking Performance: Indicators of Sustainable Manufacturing. In Eco-innovation in Industry- Enabling Green Growth; Organization for Economic Co-Operation and Development (OECD): Paris, France, 2009; pp. 95-144.

25. Scipioni, A.; Mazzi, A.; Zuliani, F.; Mason, M. The ISO 14031 standard to guide the urban sustainability measurement process: An Italian experience. J. Clean. Prod. 2008, 16, 1247-1257. [CrossRef]

26. Lammers, P.E.M.; Gilbert, A.J. Towards Environmental Pressure Indicators for the EU: Indicator Definition; EUROSTAT: Brussels, Belgium, 1999.

27. Scipioni, A.; Mazzi, A.; Mason, M.; Manzardo, A. The Dashboard of Sustainability to measure the local urban sustainable development: The case study of Padua Municipality. Ecol. Indic. 2009, 99, 364-380. [CrossRef]

28. Gatt, L. Quality of Life in New Zealand's Six Largest Cities; Auckland City Council: Auckland, New Zealand, 2001; pp. 1-122. 
29. Wackernagel, M.; Rees, W.E. Our Ecological Footprint: Reducing Human Impact on the Earth. New Catalyst Bioregional Series; New Society Publishers: Gabriola Island, BC, Canada; Philadelphia, PA, USA, 1996; Volume 9, pp. 1-160.

30. Hoekstra, A.Y.; Chapagain, A.K.; Aldaya, M.M.; Mekonnen, M.M. Water Footprint Manual—State of the Art 2009; Water Footprint Network: Enschede, The Netherlands, 2009; pp. 1-127.

31. Guijt, I.; Moiseev, A.; Prescott-Allen, R. Resource Kit for Sustainability Assessment: Part A; IUCN-The World Conversation Union: Gland, Switzerland; Cambridge, UK, 2001.

32. Eurostat 2001. Economy-wide Material Flow Accounts and Derived Indicators, A Methodological Guide; Statistical Office of the European Union: Luxembourg, 2001.

33. Bruner, P.H. Substance flow analysis-A key tool for effective resource management. J. Ind. Ecol. 2012, 16, 293-295. [CrossRef]

34. Huang, C.L.; Vause, J.; Ma, H.W.; Yu, C.P. Using material/substance flow analysis to support sustainable development assessment: A literature review and outlook. Resour. Conserv. Recycl. 2012, 68, 104-116. [CrossRef]

35. Giljum, S.; Hubacek, K. Conceptual foundations and applications of physical input-output tables. In Handbook of Input-Output Economics in Industrial Ecology, Eco-Efficiency in Industry and Science; Suh, S., Ed.; University of Minnesota: Minneapolis, MN, USA, 2009; pp. 61-75.

36. Brown, M.; Ulgiati, S. Energy quality, emergy, and transformity: H.T. Odum's contributions to quantifying and understanding systems. Ecol. Model. 2004, 178, 201-213. [CrossRef]

37. Rosen, M.; Dincer, I. Exergy as the confluence of energy, environment and sustainable development. Int. J. Exergy 2001, 1, 3-13. [CrossRef]

38. Apaiah, R.K.; Linnemann, A.R.; van der Kooi, H.J. Exergy analysis: A tool to study the sustainability of food supply chains. Food Res. Int. 2006, 39, 1-11. [CrossRef]

39. Guinèe, J.B.; Heijungs, R.; Huppes, G.; Zamangni, A.; Masoni, P.; Buonamici, R.; Ekvall, T.; Rydberg, T. Life cycle assessment: Past, present, and future. Environ. Sci. Technol. 2011, 45, 90-96. [CrossRef]

40. Bond, A.J.; Morrison-Saunders, A. Re-evaluating sustainability assessment: Aligning the vision and the practice. Environ. Impact Assess. Rev. 2011, 11, 1-7. [CrossRef]

(C) 2020 by the authors. Licensee MDPI, Basel, Switzerland. This article is an open access article distributed under the terms and conditions of the Creative Commons Attribution (CC BY) license (http://creativecommons.org/licenses/by/4.0/). 